\title{
ANALISIS RISIKO KEBANGKRUTAN DENGAN METODE ALTMAN Z-SCORE, SPRINGATE, DAN ZMIJEWSKI PADA PERUSAHAAN HIBURAN KOREA YANG TERCATAT DI BURSA KOREA TAHUN 2012 - 2016
}

\author{
A.Kadim ${ }^{1)}$ Adji Suratman $^{2)}$ dan Muhammad Abdul Muis ${ }^{3)}$
}

1,2) dosen universitas pesada idonesia YAl, email : sak kadim@yahoo.com, prof.adiisuratman@yahoo.com

3) dosen STIE YAl, email : Muhammad.muis@yahoo.co.id

\section{ARTICLES}

INFORMATION

ABSTRACT

\section{JURNAL SEKURITAS \\ (Saham, Ekonomi, Keuangan dan Investasi ) \\ Vol.2, No.2, Januari 2019 \\ Halaman : $141-155$ \\ (c) LPPM \& Prodi Manajemen \\ UNVERSITAS PAMULANG \\ ISSN (online) : 2581-2777 \\ ISSN (print) : :2581-2696}

\section{Keyword:}

Bankruptcy Analysis, Altman Z-Score, Springate,

Zmijewski, Korean

Entertainment

JEL. classification :

C33, G21, G34, N25

\section{Contact Author :}

PRODI MANAJEMEN UNPAM

JL.Surya Kencana No.1 Pamulang

Tangerang Selatan - Banten

Telp. (021) 7412566, Fax (021) 7412491 Email:

jurnalfinance.unpam@gmail.com
This study aims to analyze the risk of bankruptcy in Korean entertainment companies listed on the Korean Exchange in 20122016. The research methodology used is a comparative descriptive method with panel data and quantitative data obtained on the Korean Exchange. Sampling technique using purposive sampling method with data during the period of 2012 until 2016. Data analysis techniques used are different test techniques. The results of this research showed that calculation with altman $z-$ score was able to predicts 19 non-bankrupt companies, 3 companies in grey area, and 3 bankrupt companies. Whereas the calculation of Springate method was able to predicts 16 nonbankrupt companies and 9 bankrupt companies. And the calculation of Zmijewski method was able to predicts 25 nonbankrupt companies and 0 bankrupt companies. Compared with all these three method. The Springate method is the most effective method in predicting bankruptcy of risk companies. The Springate is more effective than the Altman Z-Score and Zmijewski method 


\section{A. Pendahuluan}

Korea Selatan merupakan sebuah negara di Asia Timur yang meliputi bagian Selatan Semenanjung Korea. Disebelah Utara, Republik Korea berbatasan dengan Korea Utara dimana keduanya bersatu sebagai Negara hingga tahun 1948. Korea Selatan tergabung dalam beberapa organisasi seperti G-20 ekonomi utama, APEC, WTO, dan OECD. Pertumbuhan ekonomi yang sangat cepat membuat negara ini dikenal dengan sebutan Macan Asia dan dikategorikan sebagai salah satu negara yang akan menguasai perekonomian di dunia di group next eleven, pertumbuhan ekonomi yang sangat pesat ini sering dijuluki dengan dijuluki dengan istilah Keajaiban Sungai Han. Korea Selatan dengan 51,25 juta jumlah penduduk pada tahun 2016 dan PDB sebesar 1,411 triliun USD pada tahun 2016, menurut data statistik ekspor tahun 2017 tercatat sebesar 15,8\% dan menduduki peringkat pertama di antara 10 negara pengekspor besar di dunia. Kesuksesan ekonomi Korea Selatan dicapai pada akhir 1980-an ketika PDB berkembang dari rata-rata $8 \%$ per tahun (US $\$ 2,7$ miliar) pada tahun 1962 menjadi US\$230 miliar pada 1989. Jumlah ini 20 kali lipat dari Korea Utara dan sama dengan ekonomi-ekonomi menengah di Uni Eropa.

Industri Korea Selatan bergerak pesat terutama atas permintaan produk elektronik. Otomotif dan telekomunikasi juga menjadi industri andalan di Korea Selatan. Ekspor Korea Selatan bergerak dalam bidang semi konduktor, peralatan telekomunikasi nirkabel, kendaraan bermotor, komputer, baja, kapal dan petrokimia. Ekonomi Korea Selatan dipimpin oleh konglomerat besar yang dikenal dengan chaebol. Beberapa chaebol yang terbesar antara lain, Samsung Electronics, POSCO, Hyundai Motor Company, KB Financial Group, Korea Electric Company, Samsung Life Insurance, Shinhan Financial Group, dan LG Electronics. Dalam seni budaya pun Korea Selatan tak ketinggalan, melalui Korean Wave ekspansi kebudayaan Korea ke seluruh dunia dilancarkan pemerintah, seperti film-film drama, musik, konser dan tariannya tumbuh secara global merambah ke sejumlah negara di berbagai belahan dunia sehingga menimbulkan "Demam Korea". Sejak tahun 1980-an, Asia Timur telah mengalami ledakan produksi budaya yang populer seperti film, musik pop, animasi, komik, program televisi, dan majalah fashion yang mana tidak hanya secara domestik melainkan lintas negara bahkan lintas regional (Otmazgin \& Ben-Ari, 2011 : 3). Korea Selatan merupakan salah satu negara di Asia, di mana pertumbuhan industri budaya sangat berkembang pesat. Salah satu demam budaya Korea yang melanda dunia adalah Korean Wave. Korean Wave atau dalam istilah lain dikenal sebagai Hallyu, sebuah istilah yang disematkan oleh jurnalis Tiongkok tahun 1990-an, di mana industri hiburan Korea Selatan seperti Korean pop populer di kalangan pemuda Tiongkok. Akibatnya, timbulah cultural exchange yang mana Hallyu memicu masyarakat Tiongkok mempelajari bahasa Korea dan termasuk kebudayaannya. Korea Selatan memang sejak lama dikenal tipikal masyarakatnya sangat menjaga nilai tradisi dan kebudayaan leluhur, sehingga tak heran jika masyarakat Korea sangat bangga dengan apa yang dikenakan, dikatakan, dan dimakan.

Karakter yang kuat pada jati diri masyarakat Korea, sebagai pemicu menguatnya nation building Korea, yang mendorong meningkatnya industri hiburan di Negeri Ginseng tersebut. Alhasil, industri yang menfasilitasi pop Korea dan drama Korea memperoleh popularitas yang tinggi di industri hiburan Asia. Sementara pada abad ke-21, Korean Wave terus berkembang di berbagai negara, mulai dari aspek gaya berpakaian, gaya penataan rambut hingga K-Pop (Korean Pop). Fenomena Korean Wave yang berhasil membius warga dunia mengenal lebih dalam kebudayaan Korea Selatan, hal tersebut telah diprediksi oleh Joseph Nye dalam Jang (2012 : 198) yang menjelaskan salah satu cara untuk melakukan soft power adalah dengan cara cultural exchanges. Cultural Exchanges menjadikan soft power yang dimiliki oleh Korea Selatan menimbulkan daya tarik tersendiri dari segi kebudayaan yang dimiliki, termasuk Korean Wave. Kelebihan dari cultural exchange selain dinikmati oleh para pelaku bisnis industri hiburan Korea, pemerintah Korea Selatan merasa diuntungkan karena berhasil membendung budaya miliki Barat dan memiliki pengaruh kuat sebagai pemiliki 
identitas Korean Wave. Pemerintah Korea melihat perkembangan pesat industri hiburan Korea akan berdampak pada semakin dikenalnya Negeri Ginseng di mata dunia dan membawa keuntungan bagi perekonomian negara juga. Seperti dari sisi industri pariwisata yang secara tidak langsung diperkenalkan dalam drama Korea. Satu hal yang harus dipahami ketika berusaha memahami fenomena ini adalah tren global K-Pop bukanlah suatu kebetulan. Korean Wave adalah hasil kolaborasi sistematis pemerintah dan pihak swasta dalam pengembangan industri kreatif Korea Selatan yang dipicu oleh krisis finansial 1997/1998. Tidak jauh berbeda dengan Indonesia, perekonomian Korea Selatan berkontraksi negatif hingga 7 persen akibat krisis finansial 1997/1998. Hal ini memaksa pemerintah Korea Selatan untuk meminjam dana dari IMF sebesar USD 97 miliar. Sama halnya dengan Indonesia pada saat krisis, terjadi lonjakan pengangguran saat itu. Untuk memulihkan kondisi ekonomi Korea Selatan dan menyerap tenaga kerja, Presiden Korea Selatan saat itu, Kim Dae-Jung mendorong pengembangan sektor-sektor industri baru. Dua sektor industri yang mendapat perhatian khusus oleh Kim Dae Jung adalah sektor teknologi informasi dan industri kreatif. Alasan dipilinnya teknologi informasi adalah karena pengembangan di sektor ini akan berdampak positif kepada sektor-sektor industri lainnya. Sedangkan dipilihnya sektor industri kreatif karena dapat mendorong ekspor produk-produk industri kreatif seperti musik, film, serta fashion sekaligus meningkatkan citra Korea Selatan. Untuk mengembangkan sektor industri kreatif dalam hal ini industri hiburan, Pemerintah Korea Selatan memberikan dukungan secara berkelanjutan mulai dari suntikan modal, subsidi, hingga insentif pajak. Tercatat pada tahun 2005, Pemerintah Korea Selatan menyuntikkan modal investasi sebesar USD 1 miliar kepada industri musik Korea Selatan. Jumlah investasi ini memang terlihat besar. Namun per tahun 2014, industri kreatif tercatat menyumbangkan USD 11,6 miliar terhadap PDB Korea Selatan. Selain injeksi modal, pemerintah Korea Selatan juga memiliki badan di bawah Kementerian Kebudayaan Korea Selatan. Divisi ini memiliki anggaran USD 500 juta dan diberi target untuk mencapai nilai ekspor industri kreatif Korea Selatan sebesar USD 10 miliar pada tahun 2019. Tidak hanya dari sisi Pemerintah, tapi sisi pelaku usaha yaitu perusahaan hiburan di Korea Selatan, mereka memiliki sistematika kerja yang sangat rapi dan menekankan kualiatas produk. Untuk mempersiapkan seorang artis K-Pop, perusahaan-perusahaan manajemen artis rata-rata menghabiskan dana sebesar USD 2-3 juta selama rentang waktu 2-3 tahun untuk persiapan dan pelatihan seorang artis sebelum dikenalkan ke publik. Dan itu hanya biaya pelatihan sang artis saja, belum dana yang dikeluarkan untuk mempersiapkan materi lagu dan promosi lebih besar lagi. Pertumbuhan industri hiburan di Korea tidak telepas dari berdirinya perusahaan-perusahaan yang bergerak dibidang hiburan seperti produksi musik, film, drama baik itu yang sudah listing di Bursa atau independen.

Bagi sebuah perusahaan apalagi perusahaan hiburan yang sudah IPO (Initial Public Offering) tentunya sangat dipengaruhi dengan isu-isu internal maupun eksternal yang jika mengalami suatu keadaan positif atau negatif internal akan mempengaruhi perusahaan tersebut. Ini disebabkan karena investor melihat perkembangan artis atau kegiatan yang dibuat oleh perusahaan itu secara langsung dan dapat dipantau terus menerus di media massa. Tentunya ini menjadi sebuah kekhawatiran bagi para investor jika ingin berinvestasi pada saham perusahaan hiburan Korea Selatan. Dimana bila tidak secara aktif memperhatikan perkembangan perindustrian ini maka para investor akan kehilangan momentum baik itu peningkatan ataupun penurunan setelahnya terlepas dari jejak laporan keuangannya. Setiap perusahaan yang berada pada tahap dewasa memiliki potensi kebangkrutan. Kebangkrutan adalah kondisi dimana perusahaan tidak mampu membayar kewajibannya kepada kreditur. Perusahaan akan mengalami kebangkrutan jika faktor penyebabnya, baik dari internal maupun eksternal tidak dapat segera diatasi. Platt (dalam Andre, 2013) menyatakan bahwa Financial Distress merupakan tahapan penurunan kondisi keuangan suatu perusahaan sebelum terjadinya kebangkrutan ataupun likuidasi. Kondisi keuangan tersebut misalnya ditinjau dari komposisi neraca yaitu perbandingan jumlah aktiva 
dan kewajiban dimana pada saat aktiva tidak cukup atau lebih kecil daripada jumlah hutangnya, modal kerja yang negatif sehingga terjadi ketidakseimbanagan modal yang dimiliki perusahaan dengan hutang piutang yang dimiliki dan berdampak pada kegiatan perusahaan dimana perusahaan tidak mampu membiayai seluruh biaya operasionalnya. Oleh karena itu, untuk mengatasi dan meminimalisir terjadinya Financial Distress, perusahaan dapat mengawasi kondisi keuangannya dari segi neraca dan laporan laba rugi yang ada dalam laporan keuangan perusahaan dengan menggunakan teknik-teknik analisis laporan keuangan.

Rumusan masalah dalam penelitian ini adalah sebagai berikut:

1. Bagaimana hasil perhitungan Metode Altman Z-Score dalam memprediksi kebangkrutan pada perusahaan hiburan Korea yang tercatat di Bursa Korea tahun 2012-2016?

2. Bagaimana hasil perhitungan Metode Springate dalam memprediksi kebangkrutan pada perusahaan hiburan Korea yang tercatat di Bursa Korea tahun 2012-2016?

3. Bagaimana hasil perhitungan Metode Zmijewski dalam memprediksi kebangkrutan pada perusahaan hiburan Korea yang tercatat di Bursa Korea tahun 2012-2016?

4. Bagaimana tingkat akurasi metode Altman Z-Score, Springate, dan Zmijewski dalam memprediksi kebangkrutan pada perusahaan hiburan Korea yang tercatat di Bursa Korea tahun 2012-2016?

\section{B. LANDASAN TEORI DAN HIPOTESIS \\ 1. Pengertian Manajemen}

Menurut Ismail Solihin (2009 : 4) manajemen dapat didefinisikan sebagai "proses perencanaan, pengorganisasian, kepemimpinan dan pengendalian dari berbagai sumber daya organisasi untuk mencapai tujuan secara efektif dan efisien".

\section{Definisi Manajemen Keuangan}

Menurut Suyono Salamun dan F.X. Isworo (2013 : 1) manajemen keuangan atau sering disebut pembelanjaan perusahaan dapat diartikan sebagai semua aktivitas perusahaan yang berhubungan dengan berbagai usaha untuk mendapatkan dana perusahaan dengan biaya yang murah, yang kemudian dana tersebut digunakan dan dialokasikan secara efisien.

\section{Pengertian Kebangkrutan}

Kebangkrutan adalah suatu kondisi di saat perusahaan mengalami ketidakcukupan dana untuk menjalani usahanya. Menurut Undang-Undang Kepailitan No.4 Tahun 1998, debitur yang mempunyai dua atau lebih kreditur dan tidak membayar sedikitnya satu hutang yang telah jatuh waktu dan dapat ditagih, dinyatakan pailit dengan putusan pengadilan yang berwenang baik atas permohonannya sendiri, maupun atas permintaan seorang atau lebih krediturnya. Kebangkrutan merupakan kegagalan perusahaan dalam menjalankan operasi perusahaan untuk menghasilkan laba. Kebangkrutan merupakan kondisi dimana perusahaan tidak mampu lagi untuk melunasi kewajibannnya.

\section{Metode Altman Z-Score}

Dalam Endri (2009) menurut The Journal of Finance Altman

pada tahun 1968, model Altman adalah model pengklasifikasi perusahaan yang sehat dan bangkrut didasarkan pada nilai $Z$ yang

diperoleh. Altman menggunakan metode step-wise multivariate discriminant analysis (MDA) dalam penelitiannya. Seperti regresi logistik, teknik stastistika ini juga bisa digunakan untuk membuat model dimana variabel dependennya merupakan kualitatif. Analisis Z-Score Altman mengkombinasikan beberapa rasio menjadi model prediksi dengan teknik statistik yaitu analisis diskriminan yang digunakan untuk memprediksi kebangkrutan perusahaan dengan metode Altman Z-Score. Dalam memprediksi 
kebangkrutan perusahaan perlu memasukkan rasio-rasio keuangan ke dalam model Altman yang dapat menentukan besarnya kemungkinan kebangkrutan. Rasio - rasio keuangan memberikan indikasi tentang kekuatan keuangan dari suatu perusahaan. Altman menemukan lima jenis rasio keuangan yang dapat dikombinasikan untuk melihat perbedaan antara perusahaan yang bangkrut dan tidak bangkrut.

\section{Metode Springate}

Dalam Peter dan Yoseph (2010) model Springate merupakan

model prediksi kebangkrutan yang didasarkan pada penelitian G. I. V. Springate pada tahun 1978, yang kemudian dikenal sebagai Model Springate atau Canadian Model. Penelitian ini dibuat dengan mengikuti prosedur yang dimodelkan oleh Altman, yaitu menggunakan stepwise multiple discriminant analysis untuk memilih empat dari sembilan belas rasio keuangan yang popular untuk membedakan dengan baik antara perusahaan yang sehat dan

perusahaan yang bangkrut (gagal).

\section{Metode Zmijewski}

Sampel model Zmijewski (1984) berjumlah 840 perusahaan, terdiri dari 40 perusahaan yang mengalami financial distress dan 800 yang tidak mengalami financial distress. Data dikumpulkan dari tahun 1972-1978. Model statistik yang digunakan Zmijewski sama dengan yang digunakan Ohlson, yaitu regresi logit.

\section{Kerangka Pemikiran}

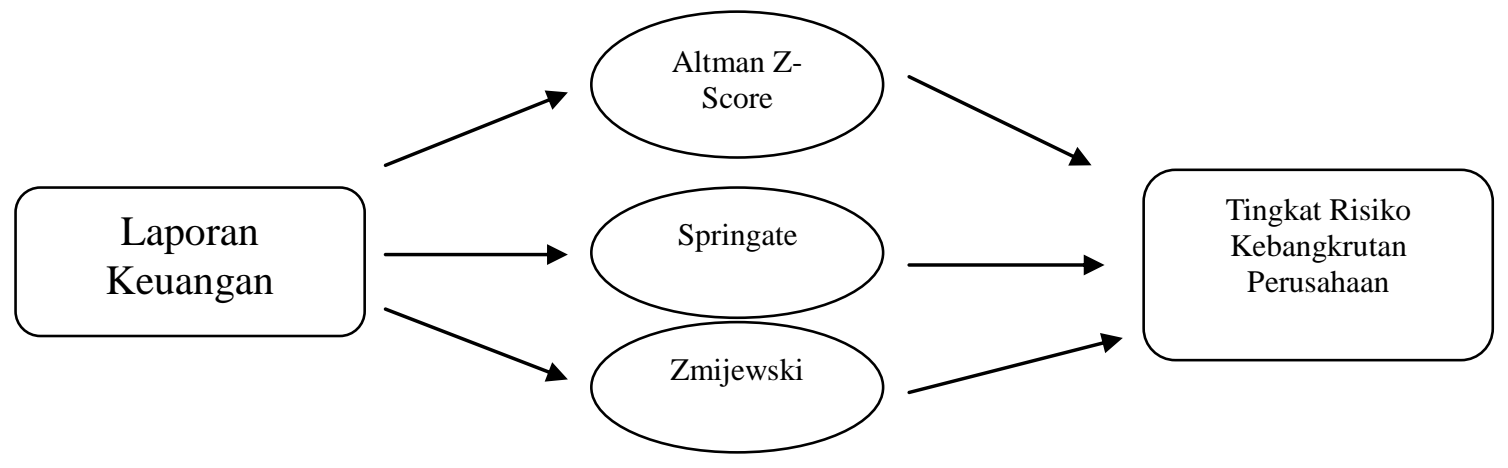

\section{HIPOTESIS}

Hipotesis adalah proporsi yang dirumuskan dengan maksud untuk diuji secara empiris. Proporsi merupakan ungkapan atau pernyataan yang dapat dipercaya, disangkal, atau diuji kebenarannya mengenal konsep atau konstruksi yang menjelaskan atau memprediksi fenomena-fenomena. Penelitian ini tanpa menggunakan hipotesis yang dirumuskan secara ketat, dimana dalam penelitian ini tidak menggunakan hipotesis untuk diuji secara statistik.

\section{METODE}

Pada penelitian ini, penelitian menggunakan metode deskriptif komparatif. Metode deskriptif adalah metode penelitian yang meneliti suatu objek, kondisi, atau peristiwa yang bertujuan untuk menjelaskan atau menggambarkan karakteristik variabel yang diteliti dalam suatu situasi. Metode komparatif yaitu membandingkan teori yang ada dengan praktik yang ditemui di lapangan. Dalam penelitian diolah data berupa laporan keuangan perusahaan dengan menghitung rasio-rasio yang ada dalam metode prediksi kebangkrutan. Setelah datanya diolah, kemudian penulis menjelaskan hasil yang didapat serta membandingkan 
metode Altman Z-Score, Springate dan Zmijewski dalam memprediksi kebangkrutan serta dari hasil tersebut meliha adanya potensi kebangkrutan pada perusahaan hiburan Korea.

Populasi adalah kumpulan suatu objek atau subjek dalam suatu wilayah yang mempunyai karakteristik yang ditentukan oleh peneliti yang dijadikan suatu pehataian untuk diteliti. Besarnya populasi yang digunakan dalam suatu penelitian tergantung pada jangkauan kesimpulan yang akan dibuat atau dihasilkan. Populasi sasaran dalam penelitian ini keseluruhan perusahaan hiburan Korea yang ada di Korea tahun 2012-2016. Sampel adalah bagian dari populasi yang kerakteristiknya hendak diduga. Dari populasi yang ada, tidak semua perusahaan hiburan Korea dalam populasi dijadikan penelitian ini karena jumlahnya yang relatif besar. Untuk efesiensi waktu dan biaya, maka digunakan teknik pemilihan sampel untuk menentukan sampel yang akan dijadikan penelitian. Sejalan dengan permasalahan yang diteliti dalam penelitian ini, maka pengambilan sampel memakai teknik Purposive Sampling. Purposive Sampling merupakan teknik sampling yang pemilihan sampelnya dilakukan secara sengaja atau tidak secara acak oleh peneliti. Jenis data dalam penelitian ini yaitu data panel (gabungan dari time series dan cross section) dan data kuantitatif. Data yang digunakan adalah data laporan keuangan tahunan dari tahun 2012 sampai dengan tahun 2016 dan 5 (lima) perusahaan hiburan Korea yang dijadikan sebagai sampel. Sumber data yang digunakan adalah data sekunder, yaitu data yang tidak dihimpun langsung oleh peneliti. Data tersebut berupa laporan keuangan perusahaan tahun 2012 sampai dengan 2016 yang telah diakses melalui www.krx.co.kr (Korean Exchange).

\section{Deskripsi Data Penelitian}

Working Capital to Total Asset (WCTA)

Rasio ini menunjukkan kemampuan perusahaan dalam menghasilkan modal kerja bersih dari total keseluruhan aktiva yang dimiliki oleh perusahaan.

Retained Earning to Total Asset (RETA)

Rasio ini menunjukkan kemampuan perusahaan dalam menghasilkan laba yang ditahan dari total keseluruhan aktiva yang dimiliki oleh perusahaan.

Earning Before Interest and Tax to Total Asset (EBITTA)

Rasio ini menggambarkan kemampuan suatu perusahaan dalam menghasilkan laba usaha dari total keseluruhan aktiva yang dimiliki oleh perusahaan.

Market Value of Equity to Book Value of Debt (MVEBVD)

Rasio ini adalah perbandingan antara nilai pasar ekuitas dengan nilai buku hutang yang menunjukkan kemampuan perusahaan untuk memenuhi kewajiban-kewajiban dari nilai pasar modal sendiri (saham biasa).

Sales to Total Asset (STA)

Rasio ini menunjukkan kemampuan perusahaan dalam menggunakan aset untuk menghasilkan penjualan. Rasio ini menujukkan apakah perusahaan menghasilkan volume bisnis yang cukup dibandingkan investasi dalam total aktivanya.

Earning Before Tax to Current Liabilities (EBTCL)

Rasio ini bertujuan mengukur perbandingan antara laba sebelum pajak yang telah dipotong dengan bunga dengan kewajiban lancar.

Return to Total Asset (ROA)

ROA merupakan salah satu rasio probabilitas yang dapat mengukur kemampuan perusahaan dalam menghasilkan laba dari aktiva yang digunakan. ROA mampu mengukur 
kemampuan perusahaan menghasilkan keuntungan pada masa lampau untuk kemudian diproyeksikan di masa yang akan datang.

Debt Ratio (DR)

Rasio ini digunakan untuk mengukur seberapa besar perusahaan mengandalkan hutang untuk membiayai asetnya.

Current Ratio (CR)

Rasio ini digunakan untuk mengukur kemampuan perusahaan dalam memenuhi kewajiban jangka pendeknya.

\section{Teknik Analisis Data}

Teknik analisis data yang digunakan adalah teknik uji beda yaitu, untuk mengetahui prediksi risiko kebangkrutan dengan menggunakan metode Altman Z-Score, Springate, dan Zmijewski.

\section{a. Metode Alman Z-Score}

Ket: $\mathrm{X}_{1}=$ Working Capital to Total Assets

Z-Score $=1,2 X_{1}+1,4 X_{2}+3,3 X_{3}+0,6 X_{4}+1,0 X_{5}$

$\mathrm{X}_{2}=$ Retained Earning to Total Assets

$\mathrm{X}_{3}=$ Earning Before Interest and Taxes to Total Assets

$\mathrm{X}_{4}=$ Market Value of Equity to Book Value of Total Debt

$\mathrm{X}_{5}=$ Sales to Total Asset

Di mana mempunyai kriteria penilaian sebagai berikut :

1) Z-Score > 2,99 diklasifikasikan sebagai perusahaan yang tidak berpotensi mengalami kebangkrutan dengan kata lain perusahaan yang sangat sehat ;

2) $1,81<$ Z-Score > 2,99 diklasifikasikan sebagai daerah abu-abu, yaitu perusahaan yang memiliki kesulitan keuangan namun kemungkinan terselamatkan dan kemungkinan bangkrut sama besarnya tergantung hasil keputusan manajemen ;

3) Z-Score < 1,81 diklasifikasikan sebagai perusahaan yang memiliki potensi besar mengalami kebangkrutan.

b. Metode Springate

$$
S=1,03 A+3,07 B+0,66 C+0,4 D
$$

Ket: $A=$ Working Capital to Total Assets

$\mathrm{B}=$ Earning before Interest \& Taxes to Total Asset

$\mathrm{C}=$ Earning before Taxes to Current Liabilities

$\mathrm{D}=$ Sales to Total Assets

Di mana mempunyai kriteria penilaian sebagai berikut :

1) $S>0,862$ diklasifikasikan sebagai perusahaan yang tidak berpotensi mengalami kebangkrutan dengan kata lain perusahaan yang sangat sehat ;

2) $S<0,862$ diklasifikasikan sebagai perusahaan yang memiliki potensi besar mengalami kebangkrutan

c. Metode Zmijewski

Ket: $\mathrm{X}_{1}=$ Return on Asset (ROA)

$$
X=-4,3-4,5 X_{1}+5,7 X_{2}+0,004 X_{3}
$$

$\mathrm{X}_{2}=$ Debt Ratio (DR)

$\mathrm{X}_{3}=$ Current Ratio (CR) 
Di mana mempunyai kriteria penilaian sebagai berikut :

a. $\mathrm{X}>0$ diklasifikasikan sebagai perusahaan tidak berpotensi mengalami kebangkrutan dengan kata lain perusahaan yang sangat sehat ;

b. $\mathrm{X}<0$ diklasifikasikan sebagai perusahaan yang memiliki potensi besar mengalami kebangkrutan

\section{E. HASIL DAN PEMBAHASAN Deskripsi Objek Penelitian}

Objek yang digunakan dalam penelitian ini adalah perusahaan hiburan Korea yang terdaftar di Bursa Korea. Sampel penelitian berdasarkan metode purposive sampling sehingga diperoleh sebanyak 5 perusahaan dengan periode selama 5 tahun yaitu 2012-2016, maka jumlah data adalah 25 data.

\begin{tabular}{|c|c|c|c|}
\hline NO & KODE & NAMA PERUSAHAAN & TANGGAL IPO \\
\hline 1 & $\begin{array}{c}\text { KOSDAQ: } \\
041510\end{array}$ & S.M Entertainment Co., Ltd. & 27 April 2000 \\
\hline 2 & $\begin{array}{c}\text { KOSDAQ: } \\
122870\end{array}$ & YG Entertainment Inc. & 23 November 2011 \\
\hline 3 & $\begin{array}{c}\text { KOSDAQ: } \\
035900\end{array}$ & JYP Entertainment Corp. & 11 Januari 2001 \\
\hline 4 & $\begin{array}{c}\text { KOSDAQ: } \\
016170\end{array}$ & Kakao M Corp. & 26 Juni 1997 \\
\hline 5 & $\begin{array}{c}\text { KOSDAQ: } \\
032800\end{array}$ & Fantagio Corp. & \\
\hline
\end{tabular}

Sumber : Data diolah penulis, 2018

\section{Hasil Analisa Data}

\section{A. Altman Z-Score}

\begin{tabular}{|c|c|c|c|c|c|}
\hline & 2012 & 2013 & 2014 & 2015 & 2016 \\
\hline \multicolumn{5}{|c|}{ SM } \\
\hline WCTA & 0,383 & 0,336 & 0,292 & 0,280 & 0,302 \\
\hline RETA & 0,260 & 0,261 & 0,284 & 0,283 & 0,250 \\
\hline EBITTA & 0,188 & 0,103 & 0,090 & 0,079 & 0,039 \\
\hline MVEBVD & 11,091 & 7,212 & 6,293 & 6,573 & 3,768 \\
\hline STA & 0,747 & 0,685 & 0,750 & 0,708 & 0,666 \\
\hline Z-SCORE & 8,85 & 6,12 & 5,95 & 5,64 & 3,77 \\
\hline \multicolumn{5}{|c|}{ YG } \\
\hline WCTA & 0,613 & 0,570 & 0,645 & 0,543 & 0,427 \\
\hline RETA & 0,380 & 0,431 & 0,215 & 0,258 & 0,226 \\
\hline EBITTA & 0,183 & 0,168 & 0,064 & 0,058 & 0,066 \\
\hline MVEBVD & 31,578 & 27,375 & 7,688 & 6,888 & 3,685 \\
\hline STA & 0,907 & 0,881 & 0,459 & 0,514 & 0,661 \\
\hline Z-SCORE & 21,72 & 19,15 & 6,36 & 5,85 & 3,92 \\
\hline \multicolumn{7}{|c|}{ JYP } \\
\hline WCTA & 0,558 & 0,204 & 0,185 & 0,200 & 0,294 \\
\hline RETA & $-2,707$ & $-0,989$ & $-0,819$ & 0,030 & 0,123 \\
\hline EBITTA & $-0,266$ & $-0,037$ & 0,112 & 0,057 & 0,160 \\
\hline MVEBVD & 12,708 & 6,307 & 7,259 & 9,372 & 7,882 \\
\hline
\end{tabular}




\begin{tabular}{|c|c|c|c|c|c|}
\hline STA & 0,613 & 0,309 & 0,656 & 0,682 & 0,851 \\
\hline Z-SCORE & 4,24 & 2,83 & 4,46 & 6,77 & 6,63 \\
\hline \multicolumn{7}{|c|}{ KAKAO M } \\
\hline WCTA & 0,480 & 0,394 & 0,476 & 0,438 & 0,432 \\
\hline RETA & 0,338 & 0,370 & 0,436 & 0,454 & 0,500 \\
\hline EBITTA & 0,174 & 0,157 & 0,192 & 0,175 & 0,176 \\
\hline MVEBVD & 7,758 & 5,568 & 11,323 & 18,187 & 12,674 \\
\hline STA & 1,069 & 1,065 & 1,064 & 0,986 & 0,993 \\
\hline Z-SCORE & 7,36 & 5,92 & 9,67 & 13,64 & 10,40 \\
\hline \multicolumn{7}{|c|}{ FANTAGIO } \\
\hline WCTA & 0,429 & 0,369 & $-0,121$ & $-0,043$ & $-0,189$ \\
\hline RETA & $-0,360$ & $-0,613$ & $-1,063$ & $-0,957$ & $-1,203$ \\
\hline EBITTA & $-0,028$ & $-0,108$ & $-0,108$ & 0,021 & $-0,102$ \\
\hline MVEBVD & 3,468 & 1,880 & 3,712 & 3,124 & 6,095 \\
\hline STA & 0,388 & 0,498 & 0,325 & 0,559 & 0,609 \\
\hline Z-SCORE & 2,39 & 0,86 & 0,56 & 1,11 & 2,02 \\
\hline
\end{tabular}

Sumber : Data Diolah Penulis, 2018

B. Springate

\begin{tabular}{|c|c|c|c|c|c|}
\hline & 2012 & 2013 & 2014 & 2015 & 2016 \\
\hline \multicolumn{6}{|c|}{ SM } \\
\hline WCTA & 0,383 & 0,336 & 0,292 & 0,280 & 0,302 \\
\hline EBITTA & 0,188 & 0,103 & 0,090 & 0,079 & 0,039 \\
\hline EBTCL & 0,758 & 0,416 & 0,345 & 0,290 & 0,168 \\
\hline STA & 0,747 & 0,685 & 0,750 & 0,708 & 0,666 \\
\hline S-SCORE & 1,770 & 1,211 & 1,104 & 1,006 & 0,810 \\
\hline \multicolumn{6}{|c|}{$Y G$} \\
\hline WCTA & 0,613 & 0,570 & 0,645 & 0,543 & 0,427 \\
\hline EBITTA & 0,183 & 0,168 & 0,064 & 0,058 & 0,066 \\
\hline EBTCL & 1,246 & 1,044 & 0,845 & 0,787 & 0,483 \\
\hline STA & 0,907 & 0,881 & 0,459 & 0,514 & 0,661 \\
\hline S-SCORE & 2,377 & 2,143 & 1,603 & 1,462 & 1,225 \\
\hline \multicolumn{6}{|c|}{ JYP } \\
\hline WCTA & 0,558 & 0,204 & 0,185 & 0,200 & 0,294 \\
\hline EBITTA & $-0,266$ & $-0,037$ & 0,112 & 0,057 & 0,160 \\
\hline EBTCL & $-1,725$ & 0,251 & 0,455 & 0,251 & 0,705 \\
\hline STA & 0,613 & 0,309 & 0,656 & 0,682 & 0,851 \\
\hline S-SCORE & $-1,133$ & 0,386 & 1,097 & 0,819 & 1,598 \\
\hline \multicolumn{6}{|c|}{ KAKAO M } \\
\hline WCTA & 0,480 & 0,394 & 0,476 & 0,438 & 0,432 \\
\hline
\end{tabular}




\begin{tabular}{|c|c|c|c|c|c|}
\hline EBITTA & 0,174 & 0,157 & 0,192 & 0,175 & 0,176 \\
\hline EBTCL & 0,705 & 0,604 & 0,623 & 0,587 & 0,559 \\
\hline STA & 1,069 & 1,065 & 1,064 & 0,986 & 0,993 \\
\hline S-SCORE & 1,922 & 1,715 & 1,918 & 1,770 & 1,751 \\
\hline \multicolumn{5}{|c|}{ FANTAGIO } \\
\hline WCTA & 0,429 & 0,369 & $-0,121$ & $-0,043$ & $-0,189$ \\
\hline EBITTA & $-0,028$ & $-1,108$ & $-0,108$ & 0,021 & $-0,102$ \\
\hline EBTCL & $-0,221$ & $-0,657$ & $-2,100$ & 0,068 & $-0,291$ \\
\hline STA & 0,388 & 0,498 & 0,352 & 0,559 & 0,609 \\
\hline S-SCORE & 0,366 & $-0,184$ & $-1,711$ & 0,290 & $-0,457$ \\
\hline
\end{tabular}

Sumber: Data Diolah Penulis, 2018

C. Zmijewski

\begin{tabular}{|c|c|c|c|c|c|}
\hline & 2012 & 2013 & 2014 & 2015 & 2016 \\
\hline \multicolumn{6}{|c|}{ SM } \\
\hline ROA & 0,104 & 0,051 & 0,009 & 0,049 & 0,009 \\
\hline DR & 0,260 & 0,321 & 0,264 & 0,296 & 0,285 \\
\hline CR & 2,664 & 2,167 & 2,315 & 2,310 & 2,179 \\
\hline X-SCORE & $-6,259$ & $-6,366$ & $-5,857$ & $-6,218$ & $-5,971$ \\
\hline \multicolumn{6}{|c|}{ YG } \\
\hline ROA & 0,153 & 0,117 & 0,050 & 0,066 & 0,038 \\
\hline $\mathrm{DR}$ & 0,171 & 0,150 & 0,277 & 0,283 & 0,280 \\
\hline CR & 4,623 & 4,844 & 7,778 & 5,825 & 4,048 \\
\hline X-SCORE & $-5,984$ & $-5,700$ & $-6,137$ & $-6,231$ & $-6,086$ \\
\hline \multicolumn{6}{|c|}{ JYP } \\
\hline ROA & $-0,401$ & $-0,056$ & 0,106 & 0,038 & 0,095 \\
\hline $\mathrm{DR}$ & 0,426 & 0,323 & 0,243 & 0,206 & 0,226 \\
\hline CR & 3,398 & 1,936 & 1,765 & 1,973 & 2,371 \\
\hline X-SCORE & $-4,939$ & $-5,899$ & $-6,170$ & $-5,654$ & $-6,024$ \\
\hline \multicolumn{6}{|c|}{ KAKAO M } \\
\hline ROA & 0,137 & 0,142 & 0,147 & 0,145 & 0,121 \\
\hline DR & 0,260 & 0,324 & 0,323 & 0,322 & 0,334 \\
\hline $\mathrm{CR}$ & 2,861 & 2,266 & 2,512 & 2,418 & 2,323 \\
\hline X-SCORE & $-6,409$ & $-6,793$ & $-6,810$ & $-6,796$ & $-6,756$ \\
\hline \multicolumn{6}{|c|}{ FANTAGIO } \\
\hline ROA & $-0,073$ & $-0,225$ & $-0,703$ & 0,025 & $-0,107$ \\
\hline DR & 0,321 & 0,364 & 0,385 & 0,390 & 0,384 \\
\hline CR & 2,483 & 2,158 & 0,638 & 0,878 & 0,480 \\
\hline
\end{tabular}




\section{X-SCORE \\ $-5,810$ \\ $-5,372$ \\ $-3,332$ \\ $-6,641$ \\ $-6,006$}

Sumber: Data Diolah Penulis, 2018

Berdasarkan tabel-tabel di atas, dari 5 perusahaan dengan sampel data sebanyak 25 sampel, yang memiliki hasil prediksi bangkrut tertinggi adalah metode Springate yaitu sebanyak 9 sampel, lalu kemudian metode Altman sebanyak 3 sampel dan metode Zmijewski tidak memiliki sampel bangkrut. Sedangkan untuk yang memiliki hasil tidak bangkrut tertinggi adalah metode Zmijewski sebanyak 25 sampel, metode Altman Z-Score sebanyak 19 sampel dan Springate sebanyak 16 sampel. Untuk penilaian grey area yang hanya dimiliki oleh Altman Z-Score dengan hasil sebanyak 3 sampel.

\section{Perbandingan Prediksi dengan Laba Bersih Perusahaan}

\begin{tabular}{|c|c|c|c|c|c|}
\hline Tahun & Kode & Net Income & Z-Score & Springate & Zmijewski \\
\hline \multirow{5}{*}{2012} & S.M & 33.523 .100 .393 & Sehat & Sehat & Sehat \\
\hline & YG & 18.026 .439 .135 & Sehat & Sehat & Sehat \\
\hline & JYP & $(9.852 .911 .220)$ & Sehat & Bangkrut & Sehat \\
\hline & KAKAO M & 23.662 .154 .378 & Sehat & Sehat & Sehat \\
\hline & FANTAGIO & $(1.844 .388 .681)$ & Abu-abu & Bangkrut & Sehat \\
\hline \multirow{5}{*}{2013} & S.M & 19.849 .297 .058 & Sehat & Sehat & Sehat \\
\hline & $Y G$ & 15.483 .619 .552 & Sehat & Sehat & Sehat \\
\hline & JYP & (3.844.643.157) & Abu-abu & Bangkrut & Sehat \\
\hline & KAKAO M & 33.649 .877 .085 & Sehat & Sehat & Sehat \\
\hline & FANTAGIO & (4.582.819.389) & Bangkrut & Bangkrut & Sehat \\
\hline \multirow{5}{*}{2014} & S.M & 3.567 .628 .237 & Sehat & Sehat & Sehat \\
\hline & YG & 17.175 .227 .165 & Sehat & Sehat & Sehat \\
\hline & JYP & 8.564 .077 .011 & Sehat & Sehat & Sehat \\
\hline & KAKAO M & 44.627 .133 .672 & Sehat & Sehat & Sehat \\
\hline & FANTAGIO & $(27.154 .037 .087)$ & Bangkrut & Bangkrut & Sehat \\
\hline \multirow{5}{*}{2015} & S.M & 22.444 .058 .246 & Sehat & Sehat & Sehat \\
\hline & $\overline{Y G}$ & 24.768 .602 .603 & Sehat & Sehat & Sehat \\
\hline & JYP & 2.815 .618 .125 & Sehat & Bangkrut & Sehat \\
\hline & KAKAO M & 52.521 .996 .642 & Sehat & Sehat & Sehat \\
\hline & FANTAGIO & 1.053 .047 .562 & Bangkrut & Bangkrut & Sehat \\
\hline \multirow{5}{*}{2016} & S.M & 4.509 .490 .310 & Sehat & Bangkrut & Sehat \\
\hline & YG & 18.578 .979 .563 & Sehat & Sehat & Sehat \\
\hline & JYP & 8.245 .738 .533 & Sehat & Sehat & Sehat \\
\hline & KAKAO M & 54.951 .434 .572 & Sehat & Sehat & Sehat \\
\hline & FANTAGIO & $(3.814 .754 .108)$ & Abu-Abu & Bangkrut & Sehat \\
\hline
\end{tabular}

Sumber: Data Diolah Penulis, 2018 
Perhitungan Tingkat Akurasi Altman Z-Score

\begin{tabular}{|c|c|c|c|c|}
\hline \multirow{2}{*}{ Rill } & \multicolumn{3}{|c|}{ Prediksi } & Total \\
\cline { 2 - 5 } & Bangkrut & Grey Area & Tidak Bangkrut & 3 \\
\hline Bangkrut & 2 & 0 & 1 & 22 \\
\hline Tidak Bangkrut & 1 & 3 & 18 & 25 \\
\hline Total & 3 & 3 & 19 & \\
\hline \multicolumn{5}{|l}{} \\
\hline Tingkat Akurasi & $83 \%$ & & \\
\hline Type Error I & $4 \%$ & & \\
\hline Type Error II & $8 \%$ & & \\
\hline Grey Area & $12 \%$ &
\end{tabular}

Sumber: Data Diolah Penulis, 2018

Berdasarkan tabel diatas, dari 5 perusahaan dengan sampel sebanyak 25 buah, maka dapat dilihat bahwa dari total 25 sampel yang sebenarnya mengalami kebangkrutan adalah 3 sampel, Altman memprediksi 2 sampel tersebut sesuai dengan sebenarnya yaitu bangkrut dan terdapat 1 sampel yang kenyataanya tidak bangkrut tetapi Altman memprediksi sampel tersebut itu bangkrut. Dari total 25 sampel yang diprediksi sehat terdapat 1 sampel yang sebenarnya mengalami kebangkrutan namun Altman memprediksi sampel tersebut sehat. Maka dari itu, Altman memiliki jumlah prediksi yang akurat yaitu sebesar $83 \%$, tetapi terdapat tingkat kesalahan tipe I sebesar $4 \%$ dan tingkat kesalahan tipe II sebesar $8 \%$.

\section{Perhitungan Tingkat Akurasi Springate}

\begin{tabular}{|c|c|c|c|}
\hline \multirow{2}{*}{ Rill } & \multicolumn{2}{|c|}{ Prediksi } & \\
\cline { 2 - 4 } & Bangkrut & Tidak Bangkrut & Total \\
\hline Bangkrut & 6 & 0 & 6 \\
\hline Tidak Bangkrut & 3 & 16 & 25 \\
\hline Total & 9 & 16 & \\
\hline \multicolumn{3}{|c|}{} \\
\hline Tingkat Akurasi & $88 \%$ & \\
\hline Type Error I & $0 \%$ & \\
\hline Type Error II & $12 \%$ \\
\hline
\end{tabular}

Sumber: Data Diolah Penulis, 2018

Berdasarkan hasil tabel diatas, dari 5 perusahaan dengan sampel sebanyak 25 sampel maka dapat dilihat bahwa total 9 perusahaan yang diprediksi bangkrut, Springate memprediksi sebenarnya ada 6 sampel yang sesuai dengan sebenarnya dan terdapat 3 sampel yang kenyataannya tidak bangkrut tetapi Springate memprediksi sampel-sampel itu bangkrut. Dan terdapat 16 sampel yang diprediksi Springate sesuai dengan keadaannya yaitu tidak bangkrut. Maka dari itu, Springate memiliki jumlah prediksi yang akurat yaitu sebesar $88 \%$, tetapi terdapat tingkat kesalahan tipe I sebesar $0 \%$ dan tipe II sebesar $12 \%$. 


\section{Perhitungan Tingkat Akurasi Zmijewski}

\begin{tabular}{|c|c|c|c|}
\hline \multirow{2}{*}{ Rill } & \multicolumn{2}{|c|}{ Prediksi } & \\
\cline { 2 - 4 } & Bangkrut & Tidak Bangkrut & Total \\
\hline Bangkrut & 0 & 6 & 6 \\
\hline Tidak Bangkrut & 0 & 19 & 19 \\
\hline Total & 0 & 25 & 25 \\
\hline \multicolumn{3}{|l}{} \\
\hline Tingkat Akurasi & $79 \%$ & \\
\hline Type Error I & $24 \%$ & \\
\hline Type Error II & $0 \%$ & \\
\hline
\end{tabular}

Sumber: Data Diolah Penulis, 2018

Berdasarkan hasil tabel diatas, dari 5 perusahaan dengan sampel sebanyak 25 sampel, maka dapat dilihat bahwa terdapat 19 sampel yang diprediksi tidak mengalami kebangkrutan sesuai dengan keadaan riilnya sedangkan terdapat 6 sampel yang keadaan riilnya bangkrut namun Zmijewski memprediksi tidak mengalami kebangkrutan. Maka dari itu, Zmijewski memiliki jumlah prediksi yang akurat yaitu sebesar $79 \%$, tetapi terdapat tingkat kesalahan tipe I sebesar $24 \%$ dan tipe kesalahan II sebesar $0 \%$.

\section{F. SIMPULAN DAN SARAN}

\section{Simpulan}

Berdasarkan hasil perhitungan analisis potensi kebangkrutan dengan menggunakan metode Altman Z-score, Springate, dan Zmijewski pada perusahaan hiburan Korea yang tercatat di Bursa Korea tahun 2012 sampai dengan 2016 dari (5) lima perusahaan dengan 25 sampel, maka dapat diketahui bagaimana perbandingan banyaknya hasil prediksi yang dianalisis dengan menggunakan Altman Z-Score, Springate, dan Zmijewski yaitu:

\begin{tabular}{|c|c|c|c|c|}
\hline \multirow{2}{*}{ METODE } & \multicolumn{3}{|c|}{ HASIL PREDIKSI } & \multirow{2}{*}{ JUMLAH } \\
\cline { 2 - 4 } & $\begin{array}{c}\text { TIDAK } \\
\text { BANGKRUT }\end{array}$ & $\begin{array}{c}\text { GREY } \\
\text { AREA }\end{array}$ & BANGKRUT & \\
\hline $\begin{array}{c}\text { ALTMAN Z- } \\
\text { SCORE }\end{array}$ & 19 & 3 & 3 & 25 \\
\hline SPRINGATE & 16 & - & 9 & 25 \\
\hline ZMIJEWSKI & 25 & - & - & 25 \\
\hline
\end{tabular}

Sumber: Data Diolah Penulis, 2018

Dan berdasarkan hasil perbandingan dalam analisa data dan pembahasan maka Springate memiliki tingkat akurasi tertinggi dibandingkan metode lainnya. Springate memiliki tingkat akurasi sebesar $88 \%$ dengan tipe error I sebesar $0 \%$ dan tipe error II sebesar $12 \%$. Metode Altman Z-Score memiliki tingkat akurasi sebesar $83 \%$ dengan tipe error I sebesar $4 \%$ dan tiper error II sebesar $8 \%$. Metode Zmijewski memiliki tingkat akurasi sebesar $79 \%$ dengan tipe error I sebesar $24 \%$ dan tipe error II sebesar 0\%. Metode Springate memiliki ketepatan yang lebih baik daripada Altman Z-Score dan Zmijewski dalam memprediksi kebangkrutan pada perusahaan hiburan Korea yang tercatat di Bursa Korea dengan menggunakan data pada laporan keuangan selama tahun 2012-2016. 


\section{Saran}

Setelah melakukan penelitian ini, peneliti mempunyai saran (1) Bagi peneliti selanjutnya, disarankan untuk menambah periode penelitian, sektor industri, variabel untuk menganalisis tingkat akurasi metode dan metode-metode prediksi kebangkrutan lainnya yang akan dibandingkan. (2) Bagi perusahaan, dari perbandingan hasil perhitungan metode Altman Z-Score, Springate dan Zmijewski dapat dijadikan sebagai pertimbangan untuk menilai kondisi perusahaan di masa yang akan datang. (3) Bagi Investor, dari perbandingan hasil perhitungan metode Altman Z-Score, Springate, dan Zmijewski dapat dijadikan pertimbangan untuk memprediksi adanya kemungkinan perusahaan akan mengalami kebangkrutan sehingga investor dapat membuat keputusan yang tepat untuk memilih perusahaan mana yang diinvestasikan.

\section{G. DAFTAR PUSTAKA}

Bimawiratma, Partisius Gerdian. 2016. Analisis Akurasi Metode Altman, Grover, Springate dan Zmijewski dalam Memprediksi Perusahaan Delisting (Studi Empiris pada Perusahaan Manufaktur di Bursa Efek Indonesia Periode 2009-2013). Skripsi. Universitas Sanata Dharma

Burhanuddin, Rizky Amalia. 2015. Analisis Penggunaan Metode Altman Z-Score dan Metode Springate untuk Mengetahui Potensi Terjadinya Financial Distress pada Perusahaan Manufaktur Sektor Industri Dasar dan Kimia Sub Sektor Semen Periode 2009-2013. Skripsi. Universitas Hasanuddin

Fitra, Halkadri. 2015. Analisis Komparasi Model Potensi Kebangkrutan Pada Perusahaan Semen Yang Terdaftar Di Bursa Efek Indonesia. Jurnal IImiah SNEMA Fakultas Ekonomi Universitas Negeri Padang

Hadad, Zulfikar. 2018. Analisis Kinerja Keuangan Dalam Memprediksi Financial Distress pada Bank Umum Syariah periode 2010-2016. Jurnal Imliah Mahasiswa UIN Syarif Hidayatullah Jakarta

Husnan, Suad dan Enny Pudjiastuti. 2012. Dasar-Dasar Manajemen Keuangan. UPP STIM YKPN. Yogyakarta

Insani, Puspa Cahya. 2017. Memprediksi Financial Distress Pada Perusahaan Asuransi Unit Syariah Periode 2011-2015 dengan Metode Altman Z-Score. Jurnal IImiah Mahasiswa Fakultas Ekonomi UIN Syarif Hidayatullah Jakarta

Meita, Elvinna WF. 2015. Analisis Penggunaan Metode Altman, Springate, dan Zmijewski dalam memprediksi kebangkrutan perusahaan pertambangan batubara periode 20122014. Jurnal IImiah Mahasiswa Fakultas Ekonomi Universitas Negeri Surabaya Vol. 3 No. 3, 2015

Nasution, Sri Hartati an. 2016. Analisis Financial Distress pada sektor Pertambangan (Studi Kasus pada Perusahaan yang Terdaftar di Bursa Efek Indonesia periode 2005-2015. Jurnal IImiah Mahasiswa UIN Syarif Hidayatullah Jakarta

Ngatijah, Siti. 2016. Perbandingan Model Prediksi Kebangkrutan (Altman, Springate, Zmijewski, Grover). Skripsi. Universitas Lampung

Peter dan Yoseph. 2011. Analisis Kebangkrutan Dengan Metode Z-Score Altman, Springate dan Zmijewski pada PT. Indofood Sukses Makmur Tbk. Periode 2005-2009. Jurnal IImiah Akuntansi Universitas Kristen Maranatha No. 4 Tahun ke-2 Januari-April 2011

Pratama, Muhammad Bani. 2016. Memprediksi Kondisi Financial Distress dengan Menggunakan Metode Altman Z-Score (Studi Empiris pada Perusahaan Property dan Real Estate yang terdaftar di Bursa Efek Indonesia periode 2011-2015. Jurnal IImiah Mahasiswa Fakultas Ekonomi UIN Syarif Hidayatullah Jakarta

Prihadi, Toto. 2013. Analisis Laporan Keuangan: Teori dan Aplikasi. Jakarta: Penerbit PPM 
Prihanthini, Ni Made E.D dan Maria M. Ratna Sari. 2013. Prediksi Kebangkrutan Dengan Model Grover, Altman Z-Score, Springate dan Zmijewski pada Perusahaan Food and Beverage di Bursa Efek. Jurnal Ilmiah Akuntasi Universitas Udayana Vol. 5 No. 2 November 2013

Rodoni, Ahmad dan Herni Ali. 2014. Manajemen Keuangan Modern. Bogor: Mitra Wacana Media

Rohutomo, Muhammad Adyan. 2017. Analisis Model Prediksi Kebangkrutan pada perusahaan ternak yang terdaftar di Bursa Efek Indonesia tahun 2011-2015. Skripsi. Universitas $\mathrm{MH}$. Thamrin

Salamun, Suyono dan F.X Isworo. 2013. Manajemen Keuangan : Investasi dan Pembiayaan. Jakarta: IFM Publishing

Solihin, Ismail. 2009. Pengantar Manajemen. Jakarta: Penerbit Erlangga

Srikandi, Khazar. 2017. Analisis Komparasi Potensi Kebangkrutan dengan metode Altman Zscore, Springate, Zmijewski pada perusahaan pertambangan (studi diambil pada perusahaan pertambangan yang terdaftar pada Bursa Efek Indonesia tahun 20122015. Skripsi. Universitas MH. Thamrin

Wibisono, Rizki Teguh, dkk. 2014. Analisis Tingkat Kebangkrutan Model Altman, Foster dan Springate pada Perusahaan Property and Real Estate Go Public di Bursa Efek Indonesia. Jurnal Online Mahasiswa Fakultas Ekonomi Universitas Riau Vzaol. 1 No. 2 Oktober 2014

Yusuf, A Muri. 2014. Metode Penelitian : Penelitian Kuantitatif dan Penelitian Gabungan. Edisi Pertama. Jakarta: Prenadamedia Group

www.krx.co.kr www.bloomberg.com 